\title{
Sociologists in Action: Sociology, Social Change, and Social Justice
}

\author{
Kathleen Odell Korgen, Shelley K. White, and Jonathan White ${ }^{1}$
}

\begin{abstract}
[Article copies available for a fee from The Transformative Studies Institute. E-mail address: journal@transformativestudies.org Website: http://www.transformativestudies.org (C2011 by The Transformative Studies Institute. All rights reserved.]
\end{abstract}

How many times have we all been posed with the seemingly central question facing sociology professors today... "But what can I do with a sociology degree?" The question, often asked by students on the cusp of

\footnotetext{
${ }^{1}$ Kathleen Odell Korgen, Ph.D., is Professor of Sociology at William Paterson University in Wayne, New Jersey. Her primary areas of specialization are race relations, racial identity, and public sociology. She has conducted trainings in corporate and campus settings on issues of diversity. Dr. Korgen's published work on race relations and racial identity includes Crossing the Racial Divide: Close Friendships Between Black and White Americans (2002) and From Black to Biracial: Transforming Racial Identity Among Americans $(1998,1999)$. Raised in Massachusetts, Dr. Korgen now lives in Montclair, New Jersey, with her husband, Jeff; daughters Julie and Jessica; and her mother, Patricia.

Jonathan M. White, Ph.D., is Assistant Professor of Sociology and Faculty Associate to Service Learning at Bridgewater State College in Massachusetts. His primary areas of specialization are inequality, poverty, globalization, human rights, and public sociology. Dr. White has received numerous teaching and humanitarian awards. He is the Founding Director of Sports for Hunger, the Hunger Resource Center, and the Halloween for Hunger and Pass-the-Fast campaigns. He serves on the board of directors for Free the Children, Peace Through Youth, the Graduation Pledge Alliance, and the Holocaust and Human Rights Center of Maine. Dr. White also has served as Director and Coordinator for Youth Ambassadors for Peace, a project aimed at helping war-affected youth. He has authored articles in the fields of inequality and globalization, and is currently writing a book entitled Hungry to Be Heard: Voices From a Malnourished America. Dr. White lives in Massachusetts with his wife, Shelley, and is the very proud uncle of 13 nieces and nephews.
}

Shelley White recently completed her Ph.D. in Sociology at Boston College, and holds a Masters degree in international Public Health. She is a Teaching Fellow at Boston College and Instructor at Simmons College. Shelley recently served as Policy Analyst at the University of Southern Maine and consultant with the Maine Department of Health and Human Services and the Ministry of Health in Lesotho, Southern Africa, on HIV/AIDS policy and programming. She has also consulted with the international nonprofit organization, Free the Children, on international development and organizational policy. Shelley studies and has published on such topics as global HIV/AIDS and public health, globalization and political economy, human rights, development, and social change. 